\title{
Extreme scoliosis from CKD-MBD resulting in respiratory failure and death
}

\author{
Satoshi Akao, ${ }^{1}$ Norihiro Nishioka, ${ }^{2}$ Hitoshi Miyasato, ${ }^{1}$ Mitsuyo Kinjo ${ }^{1}$
}

'Department of Internal Medicine, Okinawa Chubu Hospital, Uruma, Japan ${ }^{2}$ Department of Public Health, Graduate School of Medicine, Kyoto University, Kyoto, Japan

\section{Correspondence to} Dr Mitsuyo Kinjo, kinjomitsuyo@gmail.com

Accepted 28 August 2018
A) Check for updates

(c) BMJ Publishing Group Limited 2018. No commercial re-use. See rights and permissions. Published by BMJ.

To cite: Akao S, Nishioka N, Miyasato $\mathrm{H}$, et al. BMJ Case Rep Published Online First: [please include Day Month Year]. doi:10.1136/bcr-2018226249

\section{DESCRIPTION}

A 64-year-old man presented to our hospital because of dyspnoea. Twenty years ago, he had started peritoneal dialysis (PD) for chronic kidney disease. $\mathrm{He}$ had been diagnosed with secondary hyperparathyroidism 7 years before his presentation to our hospital, with an intact parathyroid hormone (PTH) $1227 \mathrm{pg} / \mathrm{mL}$ (normal range 10-60 pg/mL), calcium level of $10.1 \mathrm{mg} / \mathrm{dL}$ (normal range $8.8-10.5 \mathrm{mg}$ / $\mathrm{dL}$ ), phosphorus level of $5.5 \mathrm{mg} / \mathrm{dL}$ (normal range $2.4-4.1 \mathrm{mg} / \mathrm{dL}$ ) and alkaline phosphatase level of $377 \mathrm{IU} / \mathrm{L}$ (normal range 140-338 IU/L). His medications included cinacalcet. Ultrasonography showed a 5-milimetre nodule at the lower pole of the parathyroid, but $99 \mathrm{mTc}$-hexakis2- methoxyisobutylisonitrile (MIBI)scintigraphy revealed no abnormal accumulation.

The patient's intact PTH increased to $2606 \mathrm{pg} /$ $\mathrm{mL} 6$ years prior to presentation. At that time, the patient deferred parathyroidectomy. A year later, he switched from PD to haemodialysis. Intact PTH remained elevated to more than $4000 \mathrm{pg} / \mathrm{mL}$. His thorax became scoliotic curving to the left. $\mathrm{He}$ had experienced dyspnoea on exertion for 1 year, presenting to our hospital for an exacerbation of these symptoms. His vital signs on presentation were as follows: body temperature $36.1^{\circ} \mathrm{C}$, blood pressure $88 / 40 \mathrm{~mm} \mathrm{Hg}$, heart rate $108 / \mathrm{min}$, a respiratory rate of $24 / \mathrm{min}$ and an ambient air oxygen saturation of $88 \%$. His chest examination revealed bilateral diffuse inspiratory crackles. His arterial blood gas analysis values were: $\mathrm{pH}$ 7.14, $\mathrm{pCO}_{2}$ $89.6 \mathrm{~mm} \mathrm{Hg}, \mathrm{HCO}^{-} 29.8 \mathrm{mEq} / \mathrm{L}$. Chest radiography demonstrated cardiomegaly and remarkable thoracic deformity. His echocardiography revealed mild mitral and severe tricuspid regurgitation with probable pulmonary hypertension. We diagnosed the patient with type 2 respiratory failure and pulmonary hypertension due to severe thoracic deformity. He was intubated and placed on mechanical ventilation for 2 days. After receiving $75 \mathrm{mg}$ of cinacalcet, the patient recovered and was discharged home in 2 weeks. A month later on repeat admission, he died secondary to pneumonia and an exacerbation of his pulmonary hypertension.
*PTA: prior to admission

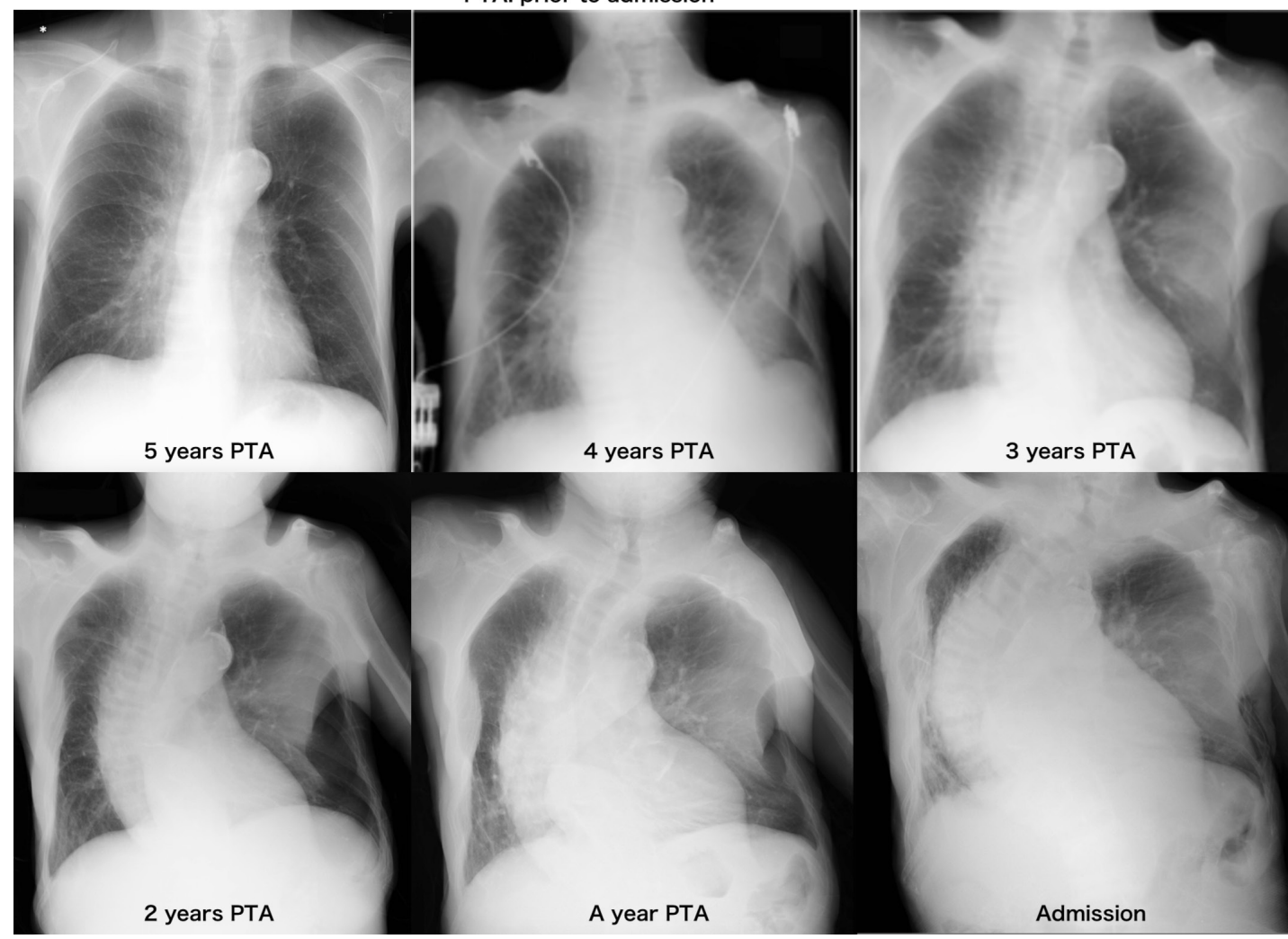

Figure 1 Chest X-ray (CXR) changes over 5 years. The CXR demonstrates thinning of the ribs and curvature of the vertebrae to the left, resulting in significant volume loss of the left lung. 


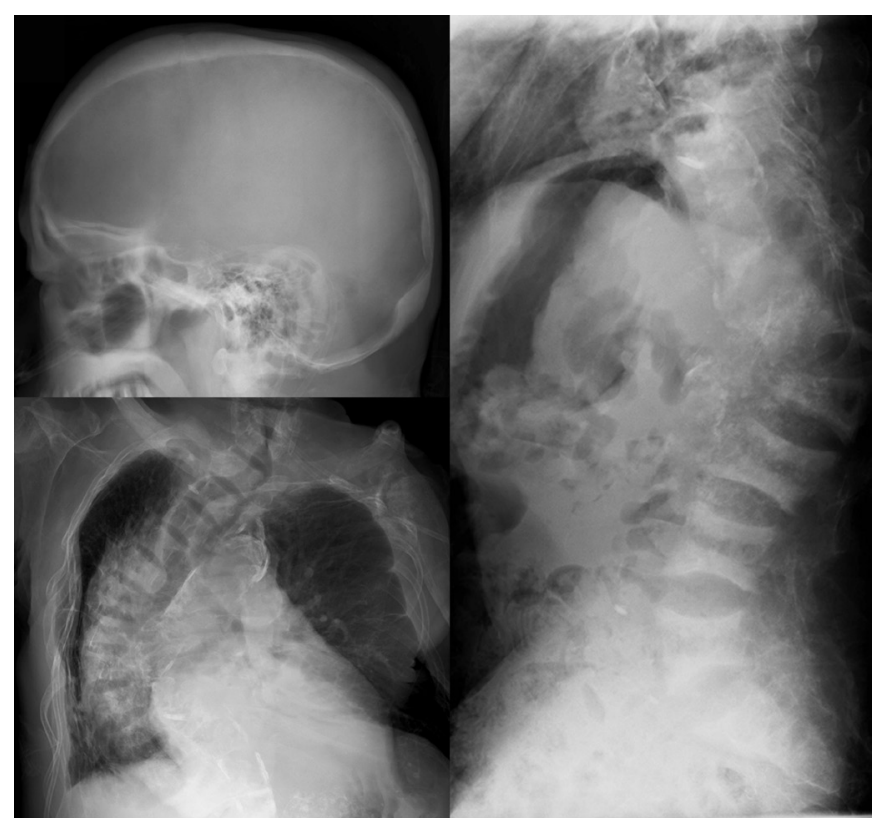

Figure 2 Reveals multiple rib fractures, rugger jersey spine and cortical thickening features classically demonstrated in chronic kidney disease-mineral bone disorder.

His chest radiography changes over 5 years are shown in figure 1 . The chest radiography demonstrates thinning of the ribs and curvature of the vertebrae to the left, resulting in significant volume loss of the left lung.

Figure 2 reveals multiple rib fractures, rugger jersey spine and cortical thickening features classically demonstrated in chronic kidney disease-mineral bone disorder (CKD-MBD).

This case illustrated untreated CKD-MBD, leading to increased bone fragility and fractures. Varying combinations of low bone mineral content and bone quality contribute to bone fragility. Osteitis fibrosa due to secondary hyperparathyroidism is one form of CKD-MBD characterised by high bone turnover, in which typical radiographic features are present as seen in this case.

Life-threatening bone deformity is a rare complication of CKD-MBD as vitamin D receptor activators and calcimimetics such as cinacalcet significantly reduce the incidence. ${ }^{1-3}$ Parathyroidectomy in combination with calcimimetics would be the choice of treatment to retard the progression of bone deformity.

\section{Learning points}

- Untreated chronic kidney disease-mineral bone disorder (CMD-MBD) causes life-threatening bone deformity.

- Repeated education and proper medications are needed for management of CKD-MBD including adjustment of calcium, phosphorus and hormonal abnormalities.

Contributors SA, NN, HM, MK: meet authorship criteria and were listed as authors. All authors certify that they have participated sufficiently in the work to take public responsibility for the content. And also participated in the concept, design, analysis and writing of the manuscript. Furthermore, each author certifies that this material or similar material has not been and will not be submitted to or published in any other publication before its appearance in the BMJ case reports.

Funding The authors have not declared a specific grant for this research from any funding agency in the public, commercial or not-for-profit sectors.

Competing interests None declared.

Patient consent Next of kin consent obtained.

Provenance and peer review Not commissioned; externally peer reviewed.

\section{REFERENCES}

1. Motosuneya T, Asazuma T, Yasuoka H, et al. Severe kyphoscoliosis associated with osteomalacia. Spine J 2006;6:587-90.

2 Dey V, Farrah TE, Traynor JP, et al. Symptomatic fracture risk in the renal replacement therapy population. Nephrol Dial Transplant 2017;32:gfw222-16.

3 Moe SM, Abdalla S, Chertow GM, et al. Effects of Cinacalcet on Fracture Events in Patients Receiving Hemodialysis: The EVOLVE Trial. J Am Soc Nephrol 2015;26:1466-75.

Copyright 2018 BMJ Publishing Group. All rights reserved. For permission to reuse any of this content visit

http://group.bmj.com/group/rights-licensing/permissions.

BMJ Case Report Fellows may re-use this article for personal use and teaching without any further permission.

Become a Fellow of BMJ Case Reports today and you can:

- Submit as many cases as you like

- Enjoy fast sympathetic peer review and rapid publication of accepted articles

- Access all the published articles

- Re-use any of the published material for personal use and teaching without further permission

For information on Institutional Fellowships contact consortiasales@bmjgroup.com

Visit casereports.bmj.com for more articles like this and to become a Fellow 